\title{
Multimedia interaktif berbasis autoplay media studio 8 untuk mata pelajaran kimia pokok bahasan laju reaksi untuk kelas XI SMA/MA
}

\section{Interactive multimedia based on autoplay media studio 8 for chemistry on rate of reaction topics for class Xi SMA/Ma}

\author{
Roza Linda $^{1 *}$; Herdini ${ }^{1}$; Zera Rahmaputri ${ }^{1}$ \\ ${ }^{1}$ Program Studi Pendidikan Kimia, FKIP, Universitas Riau, Riau-Indonesia \\ *Korespondensi: rozalinda@gmail.com
}

\begin{abstract}
Telah dikembangkan multimedia interaktif berbasis autoplay media studio 8 untuk mata pelajaran kimia pada pokok bahasan laju reaksi untuk kelas XI SMA/MA. Rancangan penelitian menggunakan desain penelitian dan pengembangan (Research and Development) dengan model Plomp, yang terdiri dari 4 fase, yaitu investigasi awal, desain, realisasi dan validasi, uji coba dan revisi. Teknik pengumpulan data dilakukan dengan memvalidasi multimedia interaktif berbasis autoplay media studio 8 kepada 3 orang validator (ahli media dan ahli materi) dan uji coba oleh praktisi (pengguna) yaitu 3 orang guru dan 15 orang peserta didik. Hasil penelitian memperlihatkan skor rata-rata penilaian validator 96,12\%. Penilaian uji kepraktisan media berdasarkan angket respon guru dan siswa masing-masing diperoleh skor rata-rata 96,25\% dan 94,5\%. Dari hasil rata-rata skor validasi dan uji coba multimedia interaktif berbasis autoplay media studio 8 untuk mata pelajaran kimia pada pokok bahasan laju reaksi untuk kelas XI SMA/MA valid dan dapat digunakan sebagai media pembelajaran.
\end{abstract}

Kata kunci: autoplay media studio 8, multimedia interaktif, laju reaksi

\begin{abstract}
A valid and practical learning Interactive Multimedia of Autoplay Media Studio 8 for Rate of Reaction topics has been developed. The research method was Research and Development with Plomp model which consist of 4 steps; Prelimenary Investigation, Design, Realization, and Validation, evaluation, revision. Media was validated by three validators and limited trial by practitioners (users). The results showed an average score of validation was $96.12 \%$. Based on questionnaire responses of 3 teachers and 20 students each earned an average score of $96.25 \%$ and $94.5 \%$, respectively. From the results of the average validation score and limited trial score of Autoplay media studio 8 Interactive Multimedia for Rate of Reaction topics was valid and can be used as a learning media.
\end{abstract}

Key words: autoplay media studio 8, interactive multimedia, rate of reaction

DOI: https://doi.org/10.24114/jpkim.v9i3.8382

Pendidik yang profesional dituntut untuk memenuhi 4 kompetensi dasar, diantaranya yaitu: kompetensi pedagogik, profesional, kepribadian dan sosial. Kompetensi pedagogik dan profesional menuntut pendidik untuk merancang desain pembelajaran yang tepat. Desain pembelajaran turut mendukung perkembangan teknologi pembelajaran yang selanjutnya digunakan juga sebagai acuan dalam mengembangkan media pembelajaran berbasis komputer (Rusman, 2012). Multimedia Interaktif berbasis komputer merupakan kombinasi dari beberapa media, misalnya teks, gambar, animasi, audio, video yang disertai dengan kontrol pengguna (user control) sehingga pengguna dapat mengontrol apa dan kapan elemen-elemen dalam multimedia akan dikirimkan atau ditampilkan. Multimedia Interaktif yang dapat digunakan saat pembelajaran harus memenuhi tiga kriteria yaitu valid, praktis dan efektif. Untuk menghasilkan produk ini maka dilakukan penelitian pengembangan.

Arsyad (2011) mengemukakan bahwa media pembelajaran berperan untuk meningkatkan aktivitas peserta didik, memotivasi peserta didik, mempermudah penyajian infomasi yang bersifat abstrak, merangsang diskusi, mengarahkan 
kegiatan peserta didik, dan memberikan pengalaman simulasi. Media pembelajaran adalah segala sesuatu yang dapat digunakan sebagai perantara untuk menyampaikan pesan (materi pembelajaran) dari pendidik (komunikator) ke peserta didik (komunikan) sehingga dapat merangsang perhatian, minat, pikiran dan perasaan pesera didik dalam kegiatan belajar untuk mencapai tujuan belajar. Media pembelajaran saat ini sudah menjadi suatu kebutuhan dalam proses pembelajaran. Penggunaan media pembelajaran dapat mengatasi kendala-kendala umum yang sering terjadi dalam proses pembelajaran, seperti keterbatasan jam di kelas, kejenuhan dalam proses pembelajaran, dan kerumitan penyampaian materi yang bersifat abstrak (Djamarah, 2008). Menurut Sadiman dkk. (2009) peranan media pembelajaran dalam proses pembelajaran dapat menghemat waktu, meningkatkan aktifitas siswa, dan mempertinggi daya ingat siswa. Media pembelajaran dikembangkan sesuai dengan permasalahan yang dihadapi oleh pendidik dan peserta didik dalam proses pembelajaran.

Salah satu pokok bahasan pada mata pelajaran kimia di SMA adalah Laju Reaksi. Menurut Hidayat dkk. (2013), Laju reaksi merupakan pokok bahasan yang mempelajari tentang teori tumbukan, perhitungan laju suatu reaksi, dan faktor-faktor yang mempengaruhi laju reaksi kimia. Secara umum, materi yang terdapat pada pokok bahasan Laju Reaksi bersifat abstrak seperti teori tumbukan. Selain itu, Submateri faktorfaktor yang mempengaruhi laju reaksi pada pokok bahasan Laju Reaksi perlu diajarkan melalui pengamatan dan praktikum. Namun, tidak semua faktor-faktor yang mempengaruhi laju reaksi dapat dipraktikumkan seperti pengaruh tekanan pada laju reaksi. Jadi, Salah satu cara untuk membantu pendidik dalam proses pembelajaran, meningkatkan minat peserta didik dalam belajar serta meningkatkan daya ingat peserta didik dibutuhkan adanya media pembelajaran interaktif pada pokok bahasan Laju Reaksi yang layak digunakan. Penelitian pengembangan media pembelajaran khususnya pada pokok Laju Reaksi pernah dilakukan oleh Linda dkk. (2016) dengan judul Pengembangan Media Pembelajaran Multimedia Interaktif Berbasis Lectora Inspire Pada Pelajaran Kimia SMA. Namun media pembelajaran dengan menggunakan Autoplay Media Studio 8 belum pernah dikembangakan pada pokok bahasan Laju Reaksi.

Media pembelajaran dapat dikembangkan dengan menggunakan software lain yang memang khusus digunakan untuk merancang media pembelajaran kimia seperti Crocodile Chemsitry
605, ChemSketch, Hyperchem, Isis Draw dan lainlain. Salah satu software yang dapat digunakan untuk mengembangkan media pembelajaran adalah Autoplay Media Studio 8. Autoplay media studio 8 merupakan aplikasi yang dirancang untuk mengembangkan aplikasi Computer Based training, sistem AutoPlay/AutoRun menu CD-ROM, presentasi marketing interaktif. Jadi, aplikasi Autoplay Media Studio 8 bukanlah aplikasi yang dikhususkan untuk media pembelajaran kimia. Akan tetapi, aplikasi Autoplay Media Studio 8 merupakan aplikasi yang berbasis Autorhing (tidak menggunakan bahasa pemrograman) yang dapat menggabungkan beragam jenis file diantaranya suara, video, gambar, flash, shape serta dilengkapi button kemana saja yang dapat membawa pengguna membuka file Ms.word, Ms.excel, Ms.powerpoint, pdf, html dan sebagainya. Dengan kemampuan aplikasi Autoplay Media Studio 8 yang beragam bisa dimanfaatkan untuk mengembangkan media pembelajaran sehingga siswa lebih tertarik untuk belajar dan dapat meningkatkan hasil belajarnya.

Media pembelajaran berbasis Autoplay Media Studio 8 pernah dikembangkan dan diuji kevalidannya oleh beberapa peneliti dan memperoleh tingkat kevalidan yang baik. Pengembangan media pembelajaran menggunakan Software Autoplay Media Studio 8 pernah dilakukan oleh Wijaya (2015) dengan perolehan skor rata-rata sebesar 91,53\%. Respon siswa pada keseluruhan aspek yang terdapat didalam media pembelajaran dinyatakan sangat baik dengan perolehan skor $84,78 \%$. Hal ini menunjukkan bahwa media pembelajaran yang dikembangkan oleh peneliti pada mata pelajaran Perekayasaan Sistem Audio di SMK Negeri 3 Surabaya layak digunakan sebagai media pembelajaran.

Penelitian pengembangan media pembelajaran dengan komputer menggunakan program Autoplay Media Studio 8 merupakan hal yang menarik dan perlu dikembangkan saat ini terkhususnya dalam bidang pendidikan. Oleh karena itu, peneliti melakukan penelitian tentang pengembangan multimedia interaktif berbasis Autoplay media studio 8 untuk mata pelajaran kimia pada pokok bahasan laju reaksi untuk kelas XI SMA/MA.

\section{Metode}

Rancangan penelitian menggunakan desain penelitian dan pengembangan (Research and Development) dengan model Plomp. Bagan prosedur penelitian $R \& D$ menggunakan model Plomp. Model Plomp terdiri dari fase investigasi 
awal; fase desain; fase realisasi/konstruksi; fase validasi, uji coba dan revisi dan implementasi. Penelitian dilaksanakan di Laboratorium Program Studi Pendidikan Kimia FKIP Universitas Riau. Uji coba terbatas dilakukan di SMA Negeri 2 Bangkinang.

Tiga orang validator menvalidasi media pembelajaran Autoplay media studio 8 yang telah dikembangkan peneliti. Validator terdiri dari dua orang ahli materi dan satu orang ahli media. Proses validasi dilakukan dengan menilai media berdasarkan lembar validasi. Analisis validitas Multimedia Interaktif Autoplay Media Studio 8 dilakukan berdasarkan aspek substansi isi, aspek desain pembelajaran, aspek tampilan (komunikasi visual) serta aspek pemanfaatan software (Kementerian Pendidikan Nasional Direktorat Jenderal Manajemen Pendidikan Dasar Dan Menengah, 2010). Teknik analisis data digunakan dalam penelitian ini adalah analisis deskriptif dengan menggunakan rumus (Ali, 2009).

$$
P=\frac{\mathrm{n}}{\mathrm{N}} \times 100 \%
$$

$P$ : persentase skor (\%), n: jumlah skor yang diperoleh, $N$ : jumlah skor maksimum

Lembar validasi untuk validator disusun berdasarkan skala likert dengan interval "baik" sampai "tidak baik" dengan empat pilihan. Setiap jawaban yang dipilih dikonversikan dengan skor 1 sampai 4. Penilaian dari semua responden dirataratakan dan persentase hasil penilaian diinterpretasikan ke dalam Tabel 1.

Tabel 1

Kriteria validitas analisis persentase (Rohmad dkk. 2013)

\begin{tabular}{cl}
\hline \multicolumn{1}{c}{ Persentase } & \multicolumn{1}{c}{ Kriteria } \\
\hline $0 \%<$ Persentase $<25 \%$ & Tidak Valid \\
$25 \%<$ Persentase $<50 \%$ & Kurang Valid \\
$50 \%<$ Persentase $<75 \%$ & Cukup Valid \\
$75 \%<$ Persentase $<100 \%$ & Valid \\
\hline
\end{tabular}

Proses uji coba dilakukan untuk menguji kepraktisan media pembelajaran berdasarkan penilaian pengguna (praktisi) melalui angket respon guru dan siswa. Tim responden adalah 3 orang guru dari 2 sekolah di kota Pekanbaru dan Bangkinang dan 20 orang peserta didik SMAN 2 bangkinang pada uji coba kelas terbatas. Peneliti menayangkan media pembelajaran di depan kelas, kemudian responden diminta mengisi lembar respon untuk memberikan penilaian tentang media pembelajaran Autoplay media studio 8.

Angket respon guru disusun berdasarkan skala Likert dengan interval Setiap respon yang diberikan guru akan mendapat nilai 4 untuk pilihan
Setuju (S), nilai 3 untuk pilihan Cukup Setuju (CS), nilai 2 untuk pilihan Kurang Setuju (KS) dan nilai 1 untuk pilihan Tidak Setuju (TS).

Angket respon siswa disusun berdasarkan skala Guttman dengan pilihan jawaban ya dan tidak. Pilihan jawaban yang dipilih dikonversikan, pilihan ya bernilai 1 dan tidak bernilai nol. Penilaian dari semua responden dirata-ratakan dan hasil penilaian yang diperoleh diinterpretasikan ke dalam Tabel 2.

Tabel 2

Kriteria kepraktisan media (Yamasari, 2011)

\begin{tabular}{|c|c|}
\hline Persentase & $\begin{array}{c}\text { Kriteria } \\
\text { Kepraktisan }\end{array}$ \\
\hline $\begin{array}{l}75 \% \leq \text { Respon media } \\
\leq 100 \%\end{array}$ & $\begin{array}{l}\text { Dapat digunakan } \\
\text { dengan tanpa revisi }\end{array}$ \\
\hline $50 \% \leq$ Respon media $\leq 75 \%$ & $\begin{array}{l}\text { Dapat digunakan } \\
\text { dengan sedikit revisi }\end{array}$ \\
\hline $25 \% \leq$ Respon media $\leq 50 \%$ & $\begin{array}{l}\text { Dapat digunakan } \\
\text { dengan banyak } \\
\text { revisi }\end{array}$ \\
\hline $0 \% \leq$ Respon media $\leq 25 \%$ & $\begin{array}{l}\text { Tidak dapat } \\
\text { digunakan }\end{array}$ \\
\hline
\end{tabular}

\section{Hasil dan Pembahasan}

\section{Produk Multimedia}

Produk berupa multimedia interaktif berbasis Autoplay Media Studio 8 untuk mata pelajara kimia pada pokok bahasan laju reaksi yang dikemas dalam bentuk CD (compact disk). Multimedia interaktif ini dikembangkan agar dapat menjadi salah satu bahan ajar bagi guru sebagai pendidik dalam menyampaikan materi pada pokok bahasan laju reaksi dan sebagai salah satu sumber belajar mandiri peserta didik sewaktu berada diluar jam sekolah. Tampilan beberapa halaman multimedia interaktif berbasis Autoplay Media Studio 8 untuk mata pelajara kimia pada pokok bahasan laju reaksi dapat dilihat pada Gbr 1, Gbr 2 dan Gbr 3.

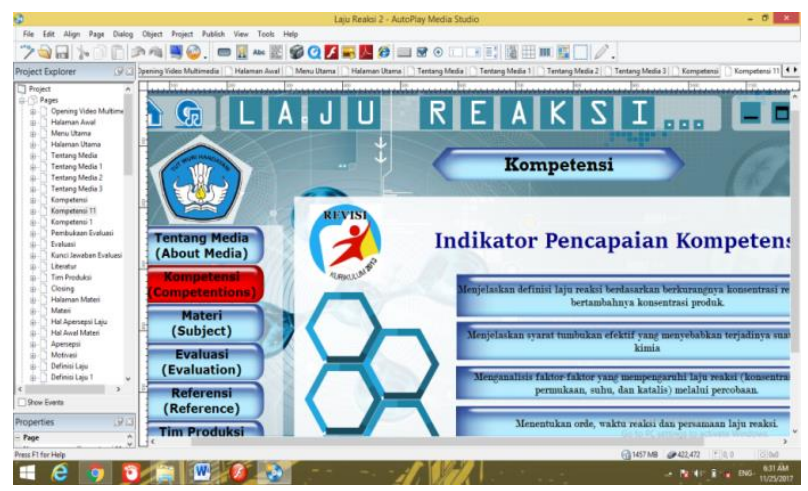

Gbr 1. Tampilan halaman kerja Autoplay Media Studio 8 


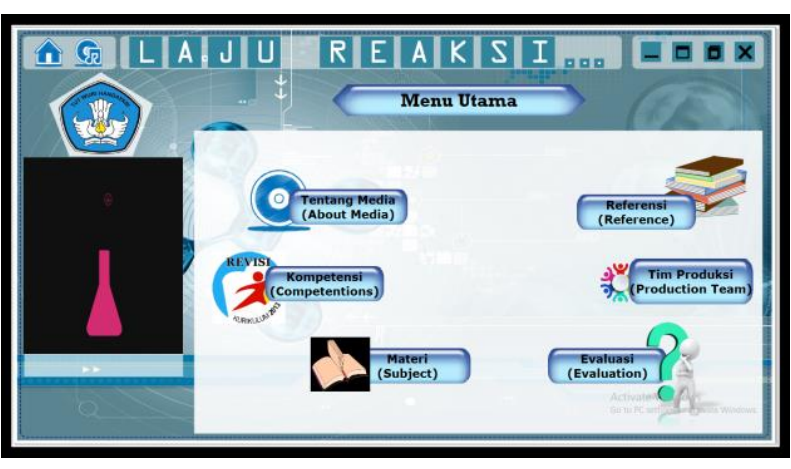

Gbr 2. Tampilan halaman Menu Utama media Autoplay Media Studio 8

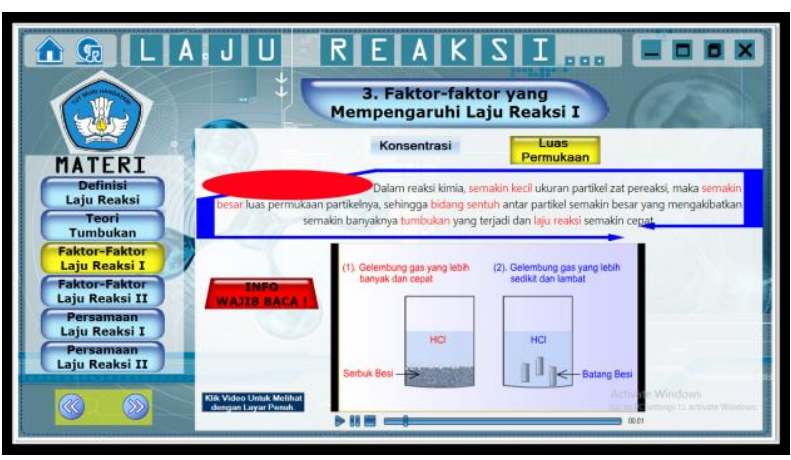

Gbr 3. Storyboard (materi ajar)

Hasil Pengembangan Media Pembelajaran berbasis Autoplay Media Studio 8

Model Plomp dilakukan untuk pengembangan media Autoplay Media Studio 8 pada pokok bahasan Laju reaksi. Tahap-tahap penelitian pengembangan dengan model Plomp adalah sebagai berikut:

\section{Fase Investigasi Awal (Prelimenary Investigation)}

Fase investigasi awal terdiri dari 4 tahap yaitu Analisis Ujung Depan, Analisis Peserta Didik, Analisis Materi dan Analisis Kompetensi. Hasil yang ditemukan adalah bahwa pokok bahasan laju reaksi termasuk salah satu pokok bahasan yang sulit dipahami oleh peserta didik. Hal ini disebabkan karena ada beberapa materi pembelajaran laju reaksi yang membutuhkan media yang dapat menvisualisasikan keadaan reaksi kimia yang berlangsung pada pokok bahasan laju reaksi. Salah satu materi yang memerlukan media tersebut adalah faktor-faktor yang mempengaruhi laju reaksi. Untuk sekolah yang kekurangan fasilitas laboratorium membutuhkan media yang dapat memberikan pengalaman praktikum secara tidak langsung sehingga peserta didik dapat memahami bagaimana faktor-faktor tersebut dapat mempengaruhi suatu laju reaksi kimia meskipun peserta didik tidak dapat melakukan praktikum. Analisis peserta didik merupakan telaah tentang karakteristik peserta didik yang sesuai dengan rancangan pengembangan media pembelajaran. Karakteristik ini meliputi kemampuan kimia yang dimiliki, sikap peserta didik terhadap pokok bahasan laju reaksi, latar belakang pengetahuan dan tingkat perkembangan kognitif peserta didik. Analisis peserta didik dibutuhkan dalam pembuatan produk media pembelajaran karena proses belajar harus disesuaikan dengan tahap perkembangan kognitif yang dilalui peserta didik. Hasil Analisis materi pada pokok bahasan laju reaksi kelas XI SMA/MA didapatkan pokok bahasan laju reaksi memerlukan pemahaman konsep dan melibatkan perhitungan.

Fase desain (design)

Hasil dari fase desain yang dilakukan antara lain: (a) Rancangan awal (blueprint) media pembelajaran interaktif. Hasil rancangan yang dihasilkan berupa historyboard media pembelajaran interaktif berbasis Autoplay Media Studio 8 yang merupakan gambaran media diatas kertas berisi tentang rancangan keseluruhan media pembelajaran yang akan dibuat. Historyboard.; (b) Animasi, video, gambar, teks, flash yang akan dimasukkan ke dalam multimedia interaktif laju reaksi sebagian diambil dari internet yang kemudian disesuaikan dengan kebutuhan peneliti. Sebagian lainnya dibuat menggunakan software pendukung seperti macromedia flash, Camtasia 8, powerpoint, dan movie maker.; dan (c) lembar validasi ahli media dan ahli materi beserta, lembar tanggapan guru dan peserta didik, serta penjabaran instrumen lembar validasi dan tanggapan.

\section{Fase realisasi (Realization)}

Pada tahap ini dihasilkan prototipe 1 (awal) sebagai realisasi hasil perancangan media.

Fase validasi, uji coba dan revisi (Test, Evaluation, Revision) a. Kegiatan Validasi; Validasi media yang dikembangkan dengan meminta pertimbangan ahli dan praktisi (validator) tentang kelayakan media pembelajaran (pada prototipe 1) yang telah direalisasikan. Digunakan instrumen berupa lembar validasi. Selanjutnya melakukan analisis terhadap hasil validasi dari validator.

b. Kegiatan Uji coba; Uji coba kelompok kecil sering juga disebut dengan uji coba terbatas. Pada tahap ini media dicobakan kepada 20 orang siswa yang mewakili populasi target di SMA N 2 Bangkinang.

c. Revisi Produk; Revisi dilakukan setiap adanya validasi dan uji coba terhadap prototipe yang kembangkan. 
Kegiatan validasi dilakukan oleh tiga validator yang terdiri dari satu ahli media dan dua ahli materi. Pada penelitian ini dilakukan validasi media oleh satu validator ahli media dan 2 validator ahli materi. Validasi merupakan penilaian valid/tidaknya produk. Penilaian produk media pembelajaran Laju Reaksi berbasis Autoplay Media Studio 8 dilakukan dalam kegiatan pengisian lembar validasi dan memberikan masukan/saran terhadap isi media. Analisis validitas Multimedia Interaktif Autoplay Media Studio 8 dilakukan berdasarkan aspek substansi isi, aspek desain pembelajaran, aspek tampilan (komunikasi visual) serta aspek pemanfaatan software

Hasil rekap penilaian masing-masing aspek diperoleh skor persentase rata-rata penilaian keempat aspek dari tiga validator yang dapat dilihat pada tabel Gbr 4.

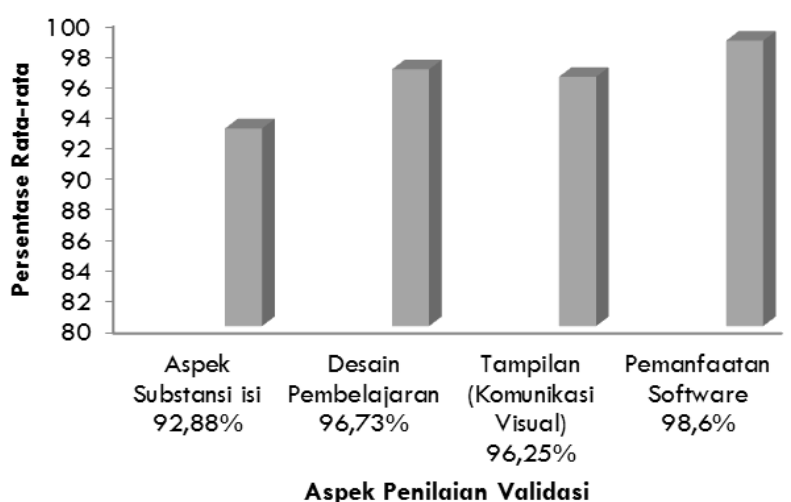

Gbr 4. Hasil validasi media

Persentase rata-rata penilaian empat aspek pengembangan diperoleh nilai tertinggi pada aspek Pemanfaatan software. Pada lembar validasi pemanfaatan software media terdapat 10 item penilaian. Validasi ini bertujuan untuk menilai respon media ketika digunakan dan kemudahan dalam penggunaan media. Validator menilai media yang dikembangkan sudah baik dari segi pengendalian media saat proses pembelajaran. Respon media terhadap perintah pengguna baik. Mudah untuk dioperasikan, menemukan informasi yang diperlukan, keluar masuk media serta mudah dalam penyimpanan. Aspek substansi memperoleh nilai terendah dari keseluruhan aspek karena masih terdapat indikator yang belum maksimal memenuhi syarat seperti penyajian soal evaluasi, umpan balik respon saat menjawab pertanyaan, dan beberapa video dan animasi yang disajikan.

Persentase rata-rata keempat aspek pada adalah 96,12\%. Mengacu pada Tabel 1 maka kriteria validitas terletak pada rentang $75 \%$ $100 \%$ dengan kategori valid. Multimedia Interaktif yang telah valid selanjutnya diuji coba kepada guru dan peserta didik. Uji coba dilakukan kepada 3 orang guru kima dari 2 SMA yaitu SMAN 8 Pekanbaru dan SMAN 2 Bangkinang. Selanjutnya dilakukan uji coba kepada 20 orang peserta didik di SMAN 2 Bangkinang. Hasil uji coba diperoleh dalam bentuk persentase dan dapat dilihat pada Tabel 3.

Tabel 3

Skor persentase penilaian uji coba

\begin{tabular}{cccl}
\hline No & $\begin{array}{c}\text { Jenis } \\
\text { Aspek }\end{array}$ & Persentase & Kriteria Kepraktisan \\
\hline 1 & Guru & 96,25 & $\begin{array}{l}\text { Dapat digunakan } \\
\text { dengan tanpa revisi }\end{array}$ \\
$2 \quad \begin{array}{c}\text { Peserta } \\
\text { didik }\end{array}$ & 94,5 & $\begin{array}{l}\text { Dapat digunakan } \\
\text { dengan tanpa revisi } \\
\text { Dapat digunakan } \\
\text { dengan tanpa revisi }\end{array}$ \\
$\begin{array}{c}\text { Persentase } \\
\text { Rata-rata }\end{array}$ & 95,38 &
\end{tabular}

Saat uji coba guru langsung berinteraksi dengan multimedia yang dioperasikan dengan laptop peneliti, sehingga guru dapat langsung menilai multimedia tanpa adanya gangguan dari unsur lain. Uji coba kepada peserta didik dilakukan dengan cara menampilkan multimedia dengan bantuan infokus. Skor persentase rata-rata penilaian uji coba diperoleh nilai tertinggi pada angket respon guru. Persentase rata-rata respon guru dan peserta didik adalah 95,38\%. Kriteria kepraktisan analisis persentase nilai terletak pada rentang 75\%-100\% dengan kategori dapat digunakan dalam pembelajaran dengan tanpa revisi. Penggunaan media pembelajaran Laju Reaksi berbasis Autoplay Media Studio 8 di sekolah membutuhkan dukungan fasilitas seperti proyektor (infocus) dan laptop atau komputer. Peserta didik juga dapat belajar mandiri menggunakan media Laju Reaksi berbasis Autoplay Media Studio 8 ini menggunakan laptop atau komputer masingmasing.

\section{Kesimpulan}

Berdasarkan penelitian pengembangan Multimedia Interaktif Autoplay Media Studio 8 yang telah dilakukan maka diperoleh kesimpulan sebagai beikut: (1) Multimedia interaktif Laju Reaksi berbasis Autoplay Media Studio 8 valid dengan skor rata-rata validitas $96,12 \%$; (2) Uji kepraktisan berdasarkan angket respon guru dan peserta didik diperoleh persentase skor rata-rata respon guru 96,25\% dan peserta didik 94,5\% dengan kriteria dapat digunakan dalam pembelajaran dengan tanpa revisi; dan (3) Media pembelajaran berbasis Autoplay Media Studio 8 valid dan dapat digunakan sebagai media pembelajaran. 


\section{Daftar Pustaka}

Rohmad, A., Suhandini, P. \& Sriyanto. (2013). Pengembangan Lembar Kerja Siswa (LKS) Berbasis Eksplorasi, Elaborasi, dan Konfirmasi (EEK) Serta Kebencanaan Sebagai Bahan Ajar Mata Pelajaran Geografi SMA/MA di Kabupate Rembang. Jurnal Edu Geography,. 1(2): 1-5.

Sadiman, A.S., Rahario, R. \& Haryono, A. (2009). Media Pendidikan; pengertian, Pengembangan dan Pemanfaatannya. Raja Grafindo Persada, Jakarta.

Arsyad, A. (2011). Media Pembelajaran. PT Raja Grafindo Persada, Jakarta.

Firman, H. (2000). Beberapa Pokok Pikiran tentang Pembelajaran Kimia di SLTA. Makalah pada diskusi Guru Kimia Aliyah Jawa Barat. BPG Bandung. http://www.harryfirman.com.

Wijaya, I. (2015). Pengembangan Media Pembelajaran Autoplay Media Studio 8 Pada Mata Pelajaran Perekayasaan Sistem Audio di SMK Negeri 3 Surabaya. Jurnal Pendidikan Teknik Elektro, IV(3):957-963.

Ali, M. (2009). Pengembangan media pembelajaran interaktif mata kuliah medah elektromagnetik. Jurnal edukasi@elektro, $5(1): 11-18$

Hidayat, R. (2013). Panduan Belajar Kimia $2 A$. Yudhistira. Jakarta.

Linda, R., Erviyenni, Noer, A.M., Oktaviani, N.A. \& Sellyna, N. (2016). Development of Lectora Inspire as Interactive Multimedia Chemistry Learning in Senior High School. Jurnal Pendidikan Kimia. 8(3):188-196.

Rusman. (2012). Belajar dan Pembelajaran Berbasis Komputer: Mengembangkan Profesionalitas Guru Abad 21. Alfabeta. Bandung.

Djamarah, S.B. (2008). Strategi Belajar Mengajar. Rineka Cipta, Jakarta.

Yamasari, Y. (2011). Pengembangan Media Pembelajaran Matematika Berbasis ICT yang Berkualitas. Seminar Nasional Pascasarjana. 